\title{
Effect of Soaking, Cooking and Germination on Chemical Constituents and Bioactive Compounds as well as their Cytotoxic Activities of Black Bean Extracts
}

\author{
Eshraq BK ${ }^{1 *}$, Mona $\mathrm{AM}^{1}$, Sayed $\mathrm{AF}^{2}$ and Emam $\mathrm{AA}^{2}$ \\ ${ }^{1}$ Crops Technology Department, Food Technology Research Institute, Agricultural Research Center, 12613 Giza, Egypt \\ ${ }^{2}$ Biochemistry Department, Faculty of Agriculture, Cairo University, 12613 Giza, Egypt
}

\begin{abstract}
Legumes are the basic diet in many populations, especially in Africa. They hold high nutritional value and they promote the human health. The aim of this investigation was to study the influence of different processing such as soaking, cooking and germination on chemical composition, phenols, tannins and flavonoids contents, as well as effects on their antioxidant and anticancer activity of black beans. Phenolic compounds of raw and processed black beans was evaluated by HPLC. The antioxidant activity was evaluated by DPPH. Anticancer activities were evaluated on five different cell lines (colon (HCT), breast (MCF7), lung (A549), prostate (PC3) and Hela (HELA). The obtained results indicated that black beans showed high protein, ash and fiber content $26.54,5.22$ and $5.58 \%$, respectively. Total phenols, tannins and isoflavonoids decreased as prolonging soaking time. The reduction percent reached high level in cooked beans. High DPPH antioxidant activity for raw black beans was observed. After $24 \mathrm{~h}$ of germination, e-vanellic acid showed the high value $56.4 \mathrm{mg} / 100 \mathrm{~g}$ followed by ferulic acid $45.38 \mathrm{mg} / 100 \mathrm{~g}$. In soaking plus cooking treatments the level of kaempferol and naringin increased. There were differences in total phenols, flavonoids and tannins content have been observed between raw and processed black beans samples that influence the antioxidant activity. Although antioxidant activity was decreased in the processed samples. Ethanol extracts of different processing exhibited cytotoxicity activities on cancer cell lines, raw sample proved to be the most active in anti-tumoral followed by germinated sample (48 h). This study demonstrated that phenolic compounds of black beans is related with soaking, cooking process and germination, and also with their anticancer activity. Strong anticancer activity toward (MCF7) cell line was observed. Anticancer activity realized a noticeable reduction of tumor inhibition after $48 \mathrm{~h}$ of germination.
\end{abstract}

Keywords: Legumes; Soaking; Germination; Cooking; Antioxidant; Cytotoxic; Cell line

\section{Introduction}

Legumes commonly used in various food preparations and formulations for both adults and children as weaning/ complimentary foods in Egyptian diet. They considered as good sources of nutritionally valuable minerals and natural dietary antioxidants and considered as potent scavengers/mopping agents of free radicals thereby which can be utilize to alleviating symptoms associated with chronic diseases.

The consumption of meat caused increases the risk of cardiovascular diseases and some types of cancer. Legumes contain a number of bioactive substances including enzyme inhibitors, phytates, lectins, phenolic compounds and oligosaccharides, which play metabolic roles in humans that frequently, consume these foods. These compounds may have protective effects against cancer $[1,2]$.

Polyphenolic compounds of legumes consist of tannins, phenolic acids and flavonoids. The legumes with the highest polyphenolic compounds content are the dark, highly pigmented varieties, such as red kidney beans and black beans. Legumes vary based on their total phenolic contents and antioxidant activity. Legumes with the highest total phenolic content (lentil, red kidney and black beans) extract had the highest antioxidant capacity. However, beans contain compounds that can negatively affect their nutritional value, such as polyphenols (especially tannins in beans) also oligosaccharides and phytase. Some of these compounds are thermolabile, disappearing after cooking and the others thermostable, but their concentrations are reduced by dissolution in water [3].

However, Ramirez-Ca'rdenas et al. [4] pointed out some studies that state that low concentrations of phenolic compounds have protective effect against cancer and. Cardiovascular diseases The positive or negative effects of these compounds seem to be more closely associated with their concentration in the beans, which varies according to type of bean, as well as their interaction with other diet's components $[4,5]$.

The over production of free radicals may lead to oxidative stress, an imbalance between the antioxidant mechanisms and the production of free radicals is observed. Oxidative stress has been showed to be associated with a variety of diseases and pathological condition, such as cancer, diabetes, obesity and autoimmune diseases [6,7].

This work aimed to study the effect of cooking and germination processing methods, on total phenols, tannins, flavonoids content as well as antioxidant and anticancer activity.

\section{Materials and Methods}

\section{Materials}

Bean: The present research work was carried out to study black bean. N (Phaseolus vulgaris) which purchased from the local market.

Chemicals: 2, 2-diphenyl-1-picrylhydrazyl (DPPH), and FolinCiocalteu reagent were obtained from LOBA chemie, India and bile extract from Win Lab Laboratory chemicals reagents, Mumbai, India. All other chemicals used were of analytical reagent grade.

*Corresponding author: Eshraq BK, Crops Technology Department, Food Technology Research Institute, Agricultural Research Center, Cairo University, 12613 Giza, Egypt, Tel: +9647722232228; E-mail: eshraqbadawi@yahoo.com

Received May 03, 2016; Accepted July 23, 2016; Published July 27, 2016

Citation: Eshraq BK, Mona AM, Sayed AF, Emam AA (2016) Effect of Soaking Cooking and Germination on Chemical Constituents and Bioactive Compounds as well as their Cytotoxic Activities of Black Bean Extracts. Nat Prod Chem Res 4 237. doi:10.4172/2329-6836.1000237

Copyright: ( 2016 Eshraq BK, et al. This is an open-access article distributed under the terms of the Creative Commons Attribution License, which permits unrestricted use, distribution, and reproduction in any medium, provided the original author and source are credited. 
Citation: Eshraq BK, Mona AM, Sayed AF, Emam AA (2016) Effect of Soaking, Cooking and Germination on Chemical Constituents and Bioactive Compounds as well as their Cytotoxic Activities of Black Bean Extracts. Nat Prod Chem Res 4: 237. doi:10.4172/2329-6836.1000237

Page 2 of 7

\section{Methods}

\section{Preparation of raw materials}

Raw black bean: Raw bean seeds were milled in a laboratory mill (IKA-Laboratechnic, Janke and Kunkel Type: MFC, Germany) to obtain a whole meal flour and kept at $-20^{\circ} \mathrm{C}$ until analysis.

Soaking of black bean: Bean seeds were soaked in distilled water for $2 \mathrm{~h}, 6 \mathrm{~h}$ and $12 \mathrm{~h}$ with a ratio 1:5 w/v and the soaked water changed twice. At the end of soaking time, the soaked water was discarded. The seeds were rinsed twice in distilled water then dried at $45 \pm 5{ }^{\circ} \mathrm{C}$ overnight in drying oven. The dried soaked seeds were milled in a laboratory mill to obtain whole meal flour and kept at

$-20{ }^{\circ} \mathrm{C}$ until analysis. Different treatments were carried out on the soaked seeds.

Cooking of soaked black bean: Soaked seeds were cooked by boiling in sufficient amounts of distilled water for $30 \mathrm{~min}$, then submerged in distilled water, and finally dried, milled and kept at $-20^{\circ} \mathrm{C}$ until analysis.

Germination of soaked black bean: Soaked seeds were germinated, placed in plastic boxes, covered with cotton cloth and left at room temperature $\left(25-27^{\circ} \mathrm{C}\right)$ for $24 \mathrm{~h}, 48 \mathrm{~h}$ and $72 \mathrm{~h}$. After that, germinated grains were sprayed with distilled water three times intervals then dried. The shoot and root portions were manually removed. The seeds were milled and kept at $-20^{\circ} \mathrm{C}$ until analysis.

\section{Chemical and biochemical analyses}

Proximate analyses: Moisture, protein, fats, crude fiber and ash contents of the raw black bean and processed were determined according to the methods of A.O.A.C. [8]. Total carbohydrate was calculated by difference. The estimated parameters were related to the untreated beans (control).

\section{Determination of antinutritional factors}

\section{Determination of phenols}

Determination of total phenol: Total phenol was determined as described by Singleton and Rossi [9]. One gram sample was mixed with $10 \mathrm{~mL} 80 \%$ methanol in a dark bottle and shaking for $2 \mathrm{~h}$. Then the mixture was filtrated. The color was developed by Folin-Ciocalteu reagent and sodium carbonate. $0.250 \mathrm{~mL}$ was mixed with $0.250 \mathrm{~mL}$ Folin-Ciocalteau reagent, $0.50 \mathrm{~mL}$ of $10 \%$ sodium carbonate $\left(\mathrm{Na}_{2} \mathrm{CO}_{3}\right)$ and the volume was completed to $5 \mathrm{~mL}$ with distilled water. After incubation in dark at room temperature for $30 \mathrm{~min}$, the absorbance of the reaction mixture was measured at $725 \mathrm{~nm}$ against blank on a spectrophotometer (UV-Vis spectrophotometer, Labomed Inc., USA). Gallic acid was chosen as a standard to prepare the standard curve. Phenols were expressed as $\mathrm{mg} / 100 \mathrm{~g}$ sample on dry weight basis.

Determination of total flavonoid: Total flavonoid was determined according to the method of Zhishen et al. [10]. Sample ( $1 \mathrm{~g})$ was mixed with $10 \mathrm{~mL} 80 \%$ methanol in a dark bottle and shaking for $2 \mathrm{~h}$. Total flavonoids extract $(0.4 \mathrm{~mL})$ were added to $4 \mathrm{~mL} \mathrm{H}_{2} \mathrm{O}$. Then $0.3 \mathrm{~mL} 5 \%$ $\mathrm{NaNO}_{2}$ was added. After $5 \mathrm{~min} 0.3 \mathrm{~mL} \mathrm{10 \%} \mathrm{AlCl}_{3}$ was added. After $6 \mathrm{~min}$ $2 \mathrm{~mL}$ of $1 \mathrm{M} \mathrm{NaOH}$ were added and the total volume was made up to 10 $\mathrm{mL}$ with distilled water. The pink color was measured at $510 \mathrm{~nm}$ against a blank reagent on a spectrophotometer (UV-Vis spectrophotometer, Labomed Inc., USA). Catechin served as standard compound was used for preparing the calibration curve. Total flavonoid was calculated as $\mathrm{mg} / 100 \mathrm{~g}$ on dry weight basis.

Determination of tannins: Tannins were determined as described by Price et al. [11]. One gram sample was mixed with $10 \mathrm{~mL} 1 \%$ methanol/ $\mathrm{HCl}$ solution in a in a dark bottle and shaking for $20 \mathrm{~min}$ at room temperature. Then the mixture was filtrated. The tannins in the supernatant were estimated by using $1 \mathrm{~mL}$ of supernatant and 5 $\mathrm{mL}$ vanillin/ $\mathrm{HCl}$ mixture (mixing equal volumes of $2 \%$ vanillin in methanol and $8 \%$ methanol/ $/ \mathrm{HCl}$ ) in a test tube and kept for $20 \mathrm{~min}$ at room temperature. The formed color was determined at $500 \mathrm{~nm}$ by using spectrophotometer (Uv-Vis spectrophotometer, Labomed Inc., USA). Catechin was used to prepare the standard curve. Tannins were calculated as $\mathrm{mg} / 100 \mathrm{~g}$ on dry weight basis.

\section{Identification of phenolic acid and flavonoid compounds}

HPLC analysis of phenolic compounds: Phenolic compounds were detected by HPLC according to the method of Goupy et al. [12] as follows: the aqueous extracts were centrifuged at $10000 \mathrm{rpm}$ (in ICE Micro-MB Centrifuge/ NARP 64606 instrument) for $10 \mathrm{~min}$ and the supernatant was filtrated through a $0.2 \mu \mathrm{m}$ Millipore membrane filter, then 1-3 mL were collected in a vial for injection into HPLC Agilent (Series 1200) equipped with auto sampler injector, solvent degasser, ultraviolet (UV) detector set at $280 \mathrm{~nm}$ and quaternary $\mathrm{HP}$ pump (Series 1100). The column [Agilent 5HC-C18 (2) $250 \times 4.6 \mathrm{~mm}$ ] temperature was maintained at $35^{\circ} \mathrm{C}$. Gradient separation was carried out with methanol and acetonitrile as a mobile phase at flow rate of $1 \mathrm{~mL} / \mathrm{min}$. Phenolic acid standards from sigma Co. were dissolved in a mobile phase and injected into HPLC. Retention time and peak area of the tested samples were calibrated against standard solutions of different phenolic compounds concentration by the data analysis of HEWLLET Packed (HP) software.

HPLC analysis of flavonoid compounds: Flavonoid fractions were also identified by HPLC according to the method of Mattila et al. [13] as follows: the aqueous extracts were centrifuged at $10000 \mathrm{rpm}$ (in ICE Micro-MB Centrifuge/ NARP 64606 instrument) for $10 \mathrm{~min}$ and the supernatant was filtrated through a $0.2 \mu \mathrm{m}$ Millipore membrane filter, then 1-3 mL were collected in a vial for injection into the previous HPLC Agilent (Series 1200) and HP software were used. The ultraviolet (UV) detector was set at $330 \mathrm{~nm}$ and the other conditions were set as that previously used in the fractionation of phenolic compounds.

\section{Determination of antioxidant activity}

Radical scavenging ability using DPPH method: The antioxidant activity of plant methanol extracts was determined based on the radical scavenging ability in reacting with a stable DPPH free radical according to Williams et al. [14]. One gram sample was extracted with $10 \mathrm{~mL} 80 \%$ methanol for $2 \mathrm{~h}$ as described above. Briefly, $2.4 \mathrm{mg}$ of DPPH in 100 $\mathrm{mL}$ methanol were prepared and $3.9 \mathrm{~mL}$ of this solution were added to $0.1 \mathrm{~mL}$ of methanolic extract. The mixture was shaken vigorously and allowed to stand in the dark for $30 \mathrm{~min}$ at room temperature. Then the absorbance was measured at $515 \mathrm{~nm}$ by using spectrophotometer (UvVis spectrophotometer, Labomed Inc., USA). Lower absorbance of the reaction mixture indicated higher free radical scavenging activity. Methanol was used as blank. The corresponding blank readings were taken and the capability to scavenge the DPPH radical was calculated using the following equation:

$\mathrm{DPPH}^{*}$ scavenging activity $(\%)=\left[\left(\mathrm{A}_{0}-\mathrm{A}_{1} / \mathrm{A}_{0}\right)\right] \times 100$

Where: $A_{0}=$ the absorbance of the control reaction (containing all reagents except the test compounds).

$\mathrm{A}_{1}=$ the absorbance in the presence of the tested extracts after $30 \mathrm{~min}$.

Measurement of potential cytotoxicity by Sulfo-Rhodamin Blue (SRB) assay: Potential cytotoxicity of the compound(s) was tested using the method of Skehan et al. [15]. Cells were plated in 96-multiwell plate 
Citation: Eshraq BK, Mona AM, Sayed AF, Emam AA (2016) Effect of Soaking, Cooking and Germination on Chemical Constituents and Bioactive Compounds as well as their Cytotoxic Activities of Black Bean Extracts. Nat Prod Chem Res 4: 237. doi:10.4172/2329-6836.1000237

Page 3 of 7

$\left(10^{4}\right.$ cells/well) for $24 \mathrm{hrs}$ before treatment with the compound(s) to allow attachment of cell to the wall of the plate. Different concentrations of the compound under test $(0,1,2.5,5$ and $10 \mu \mathrm{g} / \mathrm{mL})$ were added to the cell monolayer triplicate wells were prepared for each individual dose. Monolayer cells were incubated with the compound(s) for $48 \mathrm{hrs}$ at $37^{\circ} \mathrm{C}$ and in atmosphere of $5 \% \mathrm{CO}_{2}$. After $48 \mathrm{hrs}$, cells were fixed, washed and stained with Sulfo-Rhodamine-B stain. Excess stain was washed with acetic acid and attached stain was recovered with Tris / EDTA buffer. Color intensity was measured in an ELISA reader. The relation between surviving fraction and drug concentration is plotted to get the survival curve of each tumor cell line after the specified compound [15]. New colorimetric cytotoxicity assay for anti-cancer drug screening.

Statistical analysis: The collected data from three repetitions of any experiment were statistically analyzed in triplicate. Data were presented as mean values $\pm \mathrm{SD}$. Data were analyzed to one-way analysis of variance (ANOVA) and least significant difference (LSD) at $p<0.05$ followed by Duncan's new multiple range tests to assess differences between group's means [16].

\section{Results and Discussion}

Table 1 shows the major chemical constituents of black beans at different treatments. Protein content of raw beans was high $26.54 \%$. This result is in agreement with Vargas-Torres et al. [17], CarmonaGarc1'a et al. [18]; and Osorio-D1'az et al. [19] they reported that protein content of beans ranged from 21.2 to $23.4 \%$. Content of protein in bean was reported by Berrios et al. [20] which ranged from $25.9 \%$ to $23.3 \%$, as slightly lower $22.4 \%$. Fernández- Quintela et al. [21] found that protein content in beans ranged from 18.9 to $24.2 \%$. The crude protein was significantly decreased after different treatments compared with raw bean except for soaked beans for two hours and germinated beans for $24 \mathrm{~h}$. Nutrients loss may be attributed to the leaching of soluble nitrogen, minerals and other nutrients in desired solution as reported by Shaker et al. [22].

Fat content was $2.15 \%$ in raw beans, which significantly decreased after all processing treatments compared with raw beans. Granito et al. [23] discovered the similar amount of lipids in the investigated cultivars of bean, but Candela et al. [24] reported value of $3.50 \%$ in bean. The reduction may be due to the physiological changes during germination, which require energy to proceed, thus little part of seed oil was utilized to produce such energy. Regarding to ash and fiber content, data in the same table showed that raw black beans contained high ash and fiber $5.22 \%$ and $5.58 \%$, respectively.

After different processing treatments, ash and fiber content were significantly decreased compared with raw beans. Mubarak [25] reported that germination and cooking processes caused significant decreases in ash content. Similar values were reported in bean by Granito et al. [23]. Slightly higher value (4.65\%) was given by Berrios [20] and $(4.87 \%)$ by Candela et al. [24]. However total carbohydrate content was significantly increased after different treatments relative to raw beans $(66.10 \%)$.

The effect of soaking on total phenol, flavonoid and tannin content of black beans is given in Table 2. Total phenols showed a decrement level over soaking treatment. For instance, inhibition percent reached $(1.88 \%, 29.69 \%$ and $32.10 \%)$ after 2,6 and $12 \mathrm{~h}$ of soaking.

It cleared that total phenols was decreased as prolonging the soaking time. Same trend was observed in flavonoid content, since it reached $65.80 \mathrm{mg} / 100 \mathrm{~g}$ after $12 \mathrm{~h}$ of soaking compared with raw beans $89.82 \mathrm{mg} / 100 \mathrm{~g}$. Also tannins content showed decrement by soaking treatments, it reached $174.20,147.35$ and $86.99 \mathrm{mg} / 100 \mathrm{~g}$ after $2,6,12 \mathrm{~h}$ of soaking.

On the basis of the above mentioned discussion, the decline of total phenols, flavonoid and tannins content of black beans were increased by increasing the time of soaking and this may indicate that these components had lost in soaking water. These results are in agreement with Olivera et al. [26] and [27] and Ramirez- Cardeves et al. [4] who found a greater reduction in the content of tannins in soaked beans.

With respect to the effect of heat treatment (Table 2) it is clearly noticed that the reduction percent reached highest level in cooked beans after soaking 12 hours. The reduction level of total phenols, flavonoids and tannins content was 148.77, 65.86 and $56.94 \mathrm{mg} / 100 \mathrm{~g}$ respectively.

Regarding the germination effect on the same components, Table 2 indicates that total phenols, flavonoids and tannins showed a descending pattern of reduction. For instance total phenols reduction after 24,48 and $72 \mathrm{~h}$ of germination recorded $37.16,43.41$ and $50.40 \%$ respectively. Flavonoids reduction was $29.9,38.11$ and $49.38 \%$, while tannin recorded $60.17,64.30$ and $65.73 \%$. These results are in agreement with López et al. [28]. Who reported that after boiling and germination, was decrease in phenol concentrations of dark beans was observed.

\section{DPPH antioxidant activity}

In the past, the antioxidant characteristics of food have been studies since reactive oxygen species are widely believed to be included in many diseases such as cancer, diabetes, autoimmune con, various respiratory diseases, eye diseases, and schizophrenia Cai et al. [29]. DPPH antioxidant activity was highest in raw black beans compared to processed beans (Figure 1). The effects on DPPH were contributed by the high level of total phenols in raw beans. while the lowest value was obtained after $72 \mathrm{~h}$ of germination treatment. These results are agree with Aguilera et al. [30] and Xu and Chang [31] and Amarowicz and Pegg [32]. In the case of germination, the value of antioxidant activity depends on the days of germination, due to the variances in the enzymatic activity along the germination period Randhir et al. [33]

\section{HPLC analysis of phenolic compounds:}

Beans are good source of phenolic components. In this study sample phenolic compounds identified results at different treatments are shown in Table 3. The levels of phenolic compounds in raw black beans are $0.148 \mathrm{mg} / 100 \mathrm{~g}$ for gallic acid, $1.809 \mathrm{mg} / 100 \mathrm{~g}$ for benzoic acid, $6.627 \mathrm{mg} / 100 \mathrm{~g}$ for colorogenic acid, $20.153 \mathrm{mg} / 100 \mathrm{~g}$ for catechein, $1.717 \mathrm{mg} / 100 \mathrm{~g}$ for epi-catechin, $0.738 \mathrm{mg} / 100 \mathrm{~g}$ for p-coumaric and $1.278 \mathrm{mg} / 100 \mathrm{~g}$ for ferulic acid. From the present

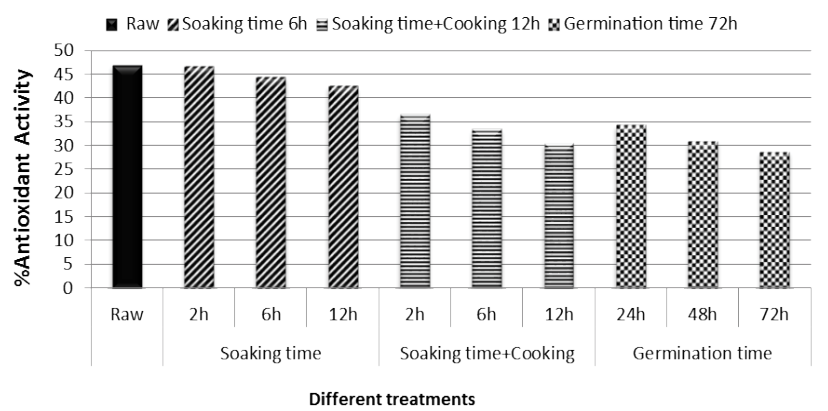

Figure 1: DPPH Activity scavenging of black bean at different processing treatments. 
Citation: Eshraq BK, Mona AM, Sayed AF, Emam AA (2016) Effect of Soaking, Cooking and Germination on Chemical Constituents and Bioactive Compounds as well as their Cytotoxic Activities of Black Bean Extracts. Nat Prod Chem Res 4: 237. doi:10.4172/2329-6836.1000237

Page 4 of 7

\begin{tabular}{|c|c|c|c|c|c|}
\hline Treatments & Protein $\%$ & Fiber\% & Oil\% & Ash\% & TC\% \\
\hline Raw & $26.54 \pm 0.15^{\mathrm{a}}$ & $5.97 \pm 0.34^{\mathrm{a}}$ & $2.15 \pm 0.04^{a}$ & $5.22 \pm 0.04^{a}$ & $66.10 \pm 0.37^{f}$ \\
\hline \multicolumn{6}{|l|}{ Soaking } \\
\hline $2 \mathrm{~h}$ & $25.98 \pm 0.29^{a}$ & $5.26 \pm 0.04^{b}$ & $1.98 \pm 0.02^{b}$ & $4.55 \pm 0.02^{b}$ & $67.50 \pm 0.36^{\mathrm{e}}$ \\
\hline $6 \mathrm{~h}$ & $24.71 \pm 0.28^{b}$ & $4.96 \pm 0.05^{\mathrm{C}}$ & $1.78 \pm 0.03^{\mathrm{d}}$ & $4.39 \pm 0.01^{\mathrm{C}}$ & $69.12 \pm 0.28^{d}$ \\
\hline $12 \mathrm{~h}$ & $23.67 \pm 0.15^{\mathrm{C}}$ & $4.56 \pm 0.10^{d}$ & $1.62 \pm 0.06^{f}$ & $4.22 \pm 0.04^{d}$ & $70.49 \pm 0.36^{C}$ \\
\hline \multicolumn{6}{|l|}{ Soaking+cooking } \\
\hline Soaking 2 h & $25.11 \pm 0.19^{a}$ & $5.12 \pm 0.03^{b c}$ & $1.79 \pm 0.04^{d}$ & $4.40 \pm 0.05^{\mathrm{C}}$ & $68.70 \pm 0.22^{d}$ \\
\hline Soaking $6 \mathrm{~h}$ & $23.04 \pm 0.16^{\mathrm{C}}$ & $4.71 \pm 0.03^{d}$ & $1.62 \pm 0.02^{f}$ & $3.99 \pm 0.12^{\mathrm{e}}$ & $71.35 \pm 0.20^{b}$ \\
\hline Soaking $12 \mathrm{~h}$ & $22.28 \pm 0.34^{d}$ & $4.54 \pm 0.04^{d}$ & $1.56 \pm 0.01^{g}$ & $3.49 \pm 0.18^{f}$ & $72.68 \pm 0.28^{a}$ \\
\hline \multicolumn{6}{|l|}{ Germination } \\
\hline $24 \mathrm{~h}$ & $26.28 \pm 0.28^{a}$ & $4.33 \pm 0.01^{\mathrm{e}}$ & $2.02 \pm 0.02^{b}$ & $4.12 \pm 0.02^{d}$ & $67.59 \pm 0.30^{\mathrm{e}}$ \\
\hline $48 \mathrm{~h}$ & $25.07 \pm 0.90^{b}$ & $4.02 \pm 0.08^{f}$ & $1.85 \pm 0.01^{\mathrm{C}}$ & $3.36 \pm 0.02^{g}$ & $69.72 \pm 0.51^{d}$ \\
\hline $72 \mathrm{~h}$ & $23.98 \pm 0.35^{C}$ & $3.78 \pm 0.01^{9}$ & $1.69 \pm 0.01^{\mathrm{e}}$ & $3.04 \pm 0.06^{h}$ & $71.30 \pm 0.09^{C}$ \\
\hline
\end{tabular}

Table 1: Proximate analysis of black beans at different treatments (dry weight basis).

\begin{tabular}{|c|c|c|c|c|c|c|}
\hline Treatments & Total phenols & Reduction \% & Flavonoids & Reduction \% & Tannins & Reduction $\%$ \\
\hline Raw & $293.28 \pm 2.48^{a}$ & 0.00 & $89.82 \pm 0.09^{a}$ & 0.00 & $214.34 \pm 6.49^{a}$ & 0.00 \\
\hline \multicolumn{7}{|l|}{ Soaking } \\
\hline Soaking $2 \mathrm{~h}$ & $287.77 \pm 7.24^{\mathrm{a}}$ & 1.88 & $84.9 \pm 0.27^{b}$ & 5.45 & $174.20 \pm 7.44^{b}$ & 19.48 \\
\hline Soaking $6 \mathrm{~h}$ & $206.21 \pm 6.36^{b}$ & 29.69 & $72.94 \pm 0.30^{C}$ & 18.80 & $147.35 \pm 3.18^{C}$ & 32.51 \\
\hline Soaking $12 \mathrm{~h}$ & $199.15 \pm 0.93^{C}$ & 32.10 & $65.80 \pm 0.24^{\mathrm{e}}$ & 26.74 & $86.99 \pm 4.13^{f}$ & 60.34 \\
\hline \multicolumn{7}{|l|}{ Soaking+cooking } \\
\hline Soaking $2 \mathrm{~h}$ & $189.91 \pm 0.55^{d}$ & 35.25 & $71.91 \pm 1.72^{C}$ & 19.94 & $87.64 \pm 1.11^{\mathrm{ef}}$ & 60.41 \\
\hline Soaking $6 \mathrm{~h}$ & $157.07 \pm 0.46^{g}$ & 46.44 & $69.61 \pm 1.09^{d}$ & 22.50 & $69.61 \pm 3.52^{d}$ & 68.83 \\
\hline Soaking $12 \mathrm{~h}$ & $148.77 \pm 0.90^{h}$ & 49.27 & $65.86 \pm 1.11^{\mathrm{e}}$ & 26.68 & $56.94 \pm 1.25^{h}$ & 74.73 \\
\hline \multicolumn{7}{|l|}{ Germination } \\
\hline $24 \mathrm{~h}$ & $184.30 \pm 1.58^{\mathrm{e}}$ & 37.16 & $62.96 \pm 0.23^{f}$ & 29.90 & $90.56 \pm 3.32^{\mathrm{e}}$ & 60.17 \\
\hline $48 \mathrm{~h}$ & $165.98 \pm 0.19^{f}$ & 43.41 & $55.59 \pm 0.45^{\mathrm{g}}$ & 38.11 & $81.87 \pm 2.73^{f g}$ & 64.30 \\
\hline $72 \mathrm{~h}$ & $145.47 \pm 0.74^{h}$ & 50.40 & $45.47 \pm 0.28^{h}$ & 49.38 & $79.27 \pm 4.49^{9}$ & 65.73 \\
\hline
\end{tabular}

Table 2: Relations between (soaking, cooking and germination) and Total phenol, flavonoid and tannin content ( $\mathrm{mg} / 100 \mathrm{~g}$ ).

\begin{tabular}{|c|c|c|c|c|c|c|c|c|c|}
\hline Treatments & Gallic & $\begin{array}{l}\text { Benzoic } \\
\text { acid }\end{array}$ & e-Vanillic & $\begin{array}{c}\text { colorogeni } \\
\text { c }\end{array}$ & Caffeine & Catechein & $\begin{array}{c}\text { Epi- } \\
\text { Catechin }\end{array}$ & P-Coumaric & Ferulic \\
\hline Raw & 0.148 & 1.809 & 23.625 & 6.627 & 0.620 & 20.153 & 1.717 & 0.738 & 1.278 \\
\hline \multicolumn{10}{|l|}{ Soaking+Cooking } \\
\hline Soaking $2 \mathrm{~h}$ & 0.131 & 21.916 & 27.055 & 1.903 & 1.630 & 13.198 & 3.319 & 1.006 & 1.853 \\
\hline Soaking $6 \mathrm{~h}$ & 0.334 & 25.546 & 25.393 & 0.983 & 0.811 & 3.743 & 2.645 & 1.537 & 2.183 \\
\hline Soaking $12 \mathrm{~h}$ & 0.147 & 14.590 & 12.940 & 0.430 & 0.450 & 2.515 & 0.982 & 0.865 & 0.769 \\
\hline \multicolumn{10}{|l|}{ Germination } \\
\hline $24 \mathrm{~h}$ & 1.501 & 29.928 & 56.942 & 2.104 & 2.463 & 21.360 & 3.157 & 1.730 & 4.539 \\
\hline $48 \mathrm{~h}$ & 0.466 & 10.853 & 48.150 & 1.996 & 1.392 & 16.253 & 2.377 & 1.463 & 2.075 \\
\hline $72 \mathrm{~h}$ & 0.467 & 8.947 & 32.410 & 0.786 & 2.107 & 11.911 & 2.221 & 0.918 & 0.918 \\
\hline
\end{tabular}

Table 3: Composition of the phenolic compounds (mg/100 g).

results there are differences in the level of the phenolic compounds as affected by different processing treatments. In soaking plus cooking treatment the level of the phenolic compounds decreased compared with raw beans. Although soaking for $6 \mathrm{~h}$ plus cooing showed increase in some phenolic acids compared with the other two soaked plus cooked samples. Regarding to germination process, germinated beans at $24 \mathrm{~h}$ had much higher phenolic compounds compared with the other samples e-vanellic acid showed the highest value $56.942 \mathrm{mg} / 100 \mathrm{~g}$ followed by ferulic $4.539 \mathrm{mg} / 100 \mathrm{~g}$. Data showed decreasing in phenolic compounds levels as prolonging the germination period $[34,35]$.

In a study of quantitation of phenols in seeds of pink beans Joseph et al. [36] found that levels of ferulic were $36.0 \mathrm{mg} / \mathrm{kg}$ while epicatechin was $2.27 \mathrm{mg} / 100 \mathrm{~g}$. In germination treatment $24 \mathrm{~h}$ e-vanillic acid had the highest concentration of $56.94 \mathrm{mg} / \mathrm{kg}$ followed by ferulic acid $45.38 \mathrm{mg} / \mathrm{kg}$ while epi-catechin had the lowest concentration $3.15 \mathrm{mg} / 100 \mathrm{~g}$. The low value of epi-catechin could be attributed to an epimerization reaction which conuers epi-catechin to its epimer catechin during the extraction process Khandelwal et al. [37]. The same authors reported that total phenolics and tannin content was decreased significantly in germinated green gram compared to Bengal gram, red gram and lentil. Loss of total phenolics and tannins content could be as high as $96 \%$ in germinated kidney bean as shown by Shimelis and Rakshit [38]. However, Duenas et al. [39] found that germination increased total phenolics content in lupin seeds after 9 days; the same results were reported by Chai [40] using germinated peanut. The observed reduction in tannin content after germination was a result formation of hydrophobic association of tannins with seed proteins and enzymes. In addition, loss of tannins during germination attribute to the leaching of tannins into the water Shimelis and Rakshit [38] and binding of polyphenols with other organic components such as protein or carbohydrate Saharan [41]. In addition, during the period of soaking and germination, the enzyme polyphenol oxidase may be activated, resulting in degradation and consequent losses of polyphenols Saxena 
Citation: Eshraq BK, Mona AM, Sayed AF, Emam AA (2016) Effect of Soaking, Cooking and Germination on Chemical Constituents and Bioactive Compounds as well as their Cytotoxic Activities of Black Bean Extracts. Nat Prod Chem Res 4: 237. doi:10.4172/2329-6836.1000237

Page 5 of 7

et al. [42], Khandewal et al. [37]. Luthria and Pastor- Corrales [43] found that caffeic acid was quantified at $1.1 \mathrm{mg} / 100 \mathrm{~g}$ in black beans, p-coumaric acid was $12.4 \mathrm{mg} / 100 \mathrm{~g}$, ferulic acid was $26.6 \mathrm{mg} / 100 \mathrm{~g}$ and sinapic acid $9.4 \mathrm{mg} / 100 \mathrm{~g}$. The data are greater than our finding results. This difference may be attributed to various factors such as storage conditions, variety, assay procedure, growing and agronomic practices (irrigation, fertilization, past management), maturity and weather changes.

\section{HPLC analysis of flavonoid compounds:}

Flavonoids compositions at different processing treatments are presented in Table 4 . In raw black beans, some flavonoids have been identified, $0.134 \mathrm{mg} / 100 \mathrm{~g}$ for kaempferol, $0.559 \mathrm{mg} / 100 \mathrm{~g}$ for hespirtin, $1.313 \mathrm{mg} / 100 \mathrm{~g}$ for quercatrin, $1.125 \mathrm{mg} / 100 \mathrm{~g}$ for rosmarinic, $8.098 \mathrm{mg} / 100 \mathrm{~g}$ for hespiridin, $1.548 \mathrm{mg} / 100 \mathrm{~g}$ for rutin, $2.346 \mathrm{mg} / 100 \mathrm{~g}$ for naringin and $2.407 \mathrm{mg} / 100 \mathrm{~g}$ for luteolin. In soaking plus cooking treatments, the level of kaempferol and naringin were increased while other identified flavonoids decreased. Quercetin was higher in raw $(1.31 \mathrm{mg} / 100 \mathrm{~g})$ and in soaked beans for $6 \mathrm{~h}$ plus cooking. The lowest concentration was observed at soaking $12 \mathrm{~h}$ plus cooking treatment for that component $(0.047 \mathrm{mg} / 100 \mathrm{~g})$. Naringin showed high concentration at 2 and 6 h soaking plus cooking ( 7.373 and 11.312$) \mathrm{mg} / 100 \mathrm{~g}$ compared with raw beans. From the same Table it is noticed that the level of kaempferol was increased at $24 \mathrm{~h}$ and 48 $\mathrm{h}$ of germination which were 2.496 and $2.138 \mathrm{mg} / 100 \mathrm{~g}$ respectively compared with raw beans $0.134 \mathrm{mg} / 100 \mathrm{~g}$, main while that compound decreased at $72 \mathrm{~h}$ of germination. Result in the same Table showed increase in quercetin in germination at 24 and $48 \mathrm{~h}(2.530$ and 2.154 $\mathrm{mg} / 100 \mathrm{~g}$, respectively) compared with raw beans $(0.133 \mathrm{mg} / 100 \mathrm{~g})$. The highest concentration was observed for naringin $(10.74 \mathrm{mg} / 100 \mathrm{~g})$ at 24 $\mathrm{h}$ of germination followed by luteolin $(9.486 \mathrm{mg} / 100 \mathrm{~g})$. Kaempferol was increased by about 19 fold compared with raw beans at $24 \mathrm{~h}$ of germination, while naringin concentration was increased by about 4 fold relative to raw beans. In the case of germination, the concentration of flavonoids depends on the days of germination, due to the variances in the enzymatic activity along the germination period Randhir et al. [33] and Kao et al. [34] reported that during soaking of soy bean, 12$57 \%$ of isoflavonoids were lost in the water. The same authors explained that leaching of isoflavonoids to the soaking water depend on time and temperature and rises by increasing temperature and time.

Some authors studied the effects of thermal processes on model solutions of phenolic compounds; these studies were led especially on flavonoids. The data indicated that flavonoids in aqueous solutions showed different sensitivity to heat processing refer to their structures. However, their structure showed significant degradation under temperature above $100{ }^{\circ} \mathrm{C}$. Rutin had a higher stability compared to it's a glycon form (quercetin) was observed Buchner et al. [35]; Friedman [44]; Makris and Rossiter [45]. These findings are attributed to the prevention of carbanion formation due to the glycosylation of the 3-hydroxyl group in the C-ring Buchner et al. [35]; Friedman [44]. Luteolin had more stability to heat than luteolin-7-glucoside and rutin when heated at $180^{\circ} \mathrm{C}$ for $180 \mathrm{~min}$ Murakami et al. [46]. The degradation of flavonoids was not only a function of temperature and magnitude of heating; it refers also to other parameters such as $\mathrm{pH}$, phytochemicals, and structure and even the presence or absence of oxygen. Indeed, original flavonol concentration had no effect on the degradation of rutin and quercetin. Moreover, under weak basic Buchner et al. [35]; Friedman [44] and neutral Friedman [44] reaction conditions, more degradation of rutin and quercetin was observed Buchner et al. [35]. The absence of oxygen highly decreased quercetin degradation and prevents rutin breaking up during heating. The presence of oxygen was shown to accelerate quercetin and rutin degradation due to the presence of the reactive oxygen species Buchner et al. [35] and Makris and Rossiter [45]. Colorogenic acid was observed to protect rutin against degradation when a mixture of the two substances was heated at $180^{\circ} \mathrm{C}$ Murakami et al. [46]

\section{Anti-cancer activity}

The black beans extract was found to express HCT, MCF7, A549, PC3 and HELA cancer inhibitory activity when tested at concentrations of 5-50 $\mu \mathrm{g} / \mathrm{mL}$ toward MCF-7 cell line followed by A549, HELA, HCT and PC 3 cell line, 20.8, 21.8, 23.6 and $32.3 \mu \mathrm{g} / \mathrm{mL}$, respectively.

Tables 5 and 6 (Figure 2) shows the cytotoxic effects of raw, soaked with cooked, and germinated black beans extracts on breast cancer cell line (MCF7). Strong anticancer activity toward MCF7 cell line was observed for raw bean extract, which $\mathrm{IC}_{50}$ recorded $17.3 \mu \mathrm{g} / \mathrm{mL}$, which had the lowest the $\mathrm{IC}_{50}$ value, the highest the anticancer activity of the extract.

Regarding to heat treatment, results revealed that the anticancer activity of bean extract was dependent on the soaking time before cooking (Figure 3). More specifically, bean extract (soaking $12 \mathrm{~h}+$ cooking) exhibited higher anticancer activity than the other two cooked bean extracts (soaking $2 \mathrm{~h}$ and $6 \mathrm{~h}+$ cooking).

Cytotoxic activity of bean extracts during different germination periods $(24,48$ and $72 \mathrm{~h}$ ) are given in the same Figure 3. From which

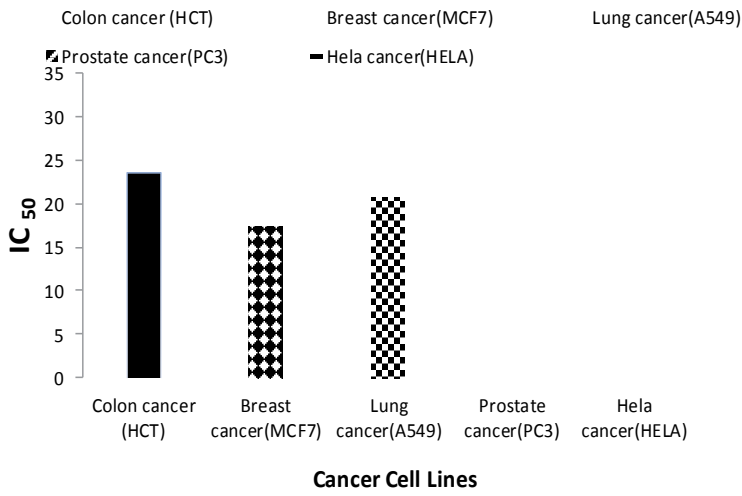

Figure 2: The inhibition of cell growth by different cell lines of black bean

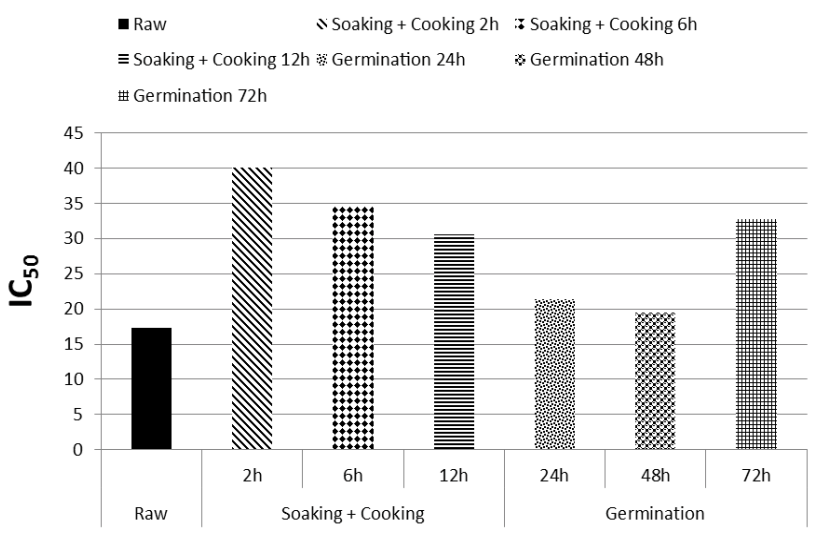

Breast cancer MCF-7

Figure 3: The inhibition of cell growth by different treatments of black bean. 
Citation: Eshraq BK, Mona AM, Sayed AF, Emam AA (2016) Effect of Soaking, Cooking and Germination on Chemical Constituents and Bioactive Compounds as well as their Cytotoxic Activities of Black Bean Extracts. Nat Prod Chem Res 4: 237. doi:10.4172/2329-6836.1000237

Page 6 of 7

\begin{tabular}{|c|c|c|c|c|c|c|c|c|c|}
\hline Treatments & Kaempferol & Hespirtin & Quercetin & Quercetrin & Rosmarinic & Hespiridin & Rutin & Naringin & Luteolin \\
\hline Raw & 0.134 & 0.559 & 1.313 & 1.069 & 1.125 & 8.098 & 1.548 & 2.346 & 2.407 \\
\hline \multicolumn{10}{|c|}{ Soaking +Cooking } \\
\hline Soaking $2 \mathrm{~h}$ & 1.418 & 3.179 & 0.444 & 0.294 & 0.865 & 2.140 & 2.939 & 7.373 & 1.295 \\
\hline Soaking $6 \mathrm{~h}$ & 1.330 & 0.948 & 1.130 & 0.283 & 1.311 & 1.933 & 1.061 & 11.312 & 4.085 \\
\hline Soaking $12 \mathrm{~h}$ & 0.261 & 0.579 & 0.047 & 0.060 & 0.107 & 2.198 & 0.454 & 0.974 & 0.391 \\
\hline \multicolumn{10}{|l|}{ Germination } \\
\hline $24 \mathrm{~h}$ & 2.496 & 0.698 & 2.530 & 1.108 & 2.126 & 2.687 & 3.539 & 10.747 & 9.486 \\
\hline $48 \mathrm{~h}$ & 2.138 & 0.322 & 2.154 & 0.501 & 1.202 & 15.201 & 2.715 & 9.536 & 2.888 \\
\hline $72 \mathrm{~h}$ & 1.457 & 0.737 & 0.219 & 0.153 & 0.969 & 6.860 & 1.300 & 3.748 & 0.601 \\
\hline
\end{tabular}

Table 4: Composition of flavonoid compounds $(\mathrm{mg} / 100 \mathrm{~g})$.

\begin{tabular}{|c|c|c|c|c|}
\hline $\begin{array}{c}\text { Cell lines } \\
\text { Conc. } \mathbf{\mu g} / \mathbf{m L}\end{array}$ & Colon cancer (HCT) & $\begin{array}{c}\text { Breast cancer } \\
\text { (MCF7) }\end{array}$ & $\begin{array}{c}\text { Lung cancer } \\
\text { (A549) }\end{array}$ & $\begin{array}{c}\text { Prostate cancer } \\
\text { (PC3) }\end{array}$ \\
\hline 0.00 & 1.00 & 1.00 & 1.00 & 1.00 \\
\hline 5.00 & 0.846 & 0.867 & 0.958 & 0.876 \\
\hline 12.50 & 0.793 & 0.659 & 0.773 & 0.738 \\
\hline 25.00 & 0.461 & 0.260 & 0.371 & 0.825 \\
\hline 50.00 & 0.61 & 0.194 & 0.176 & 0.608 \\
\hline IC50 & 23.6 & 17.30 & 0.425 & 0.241 \\
\hline
\end{tabular}

Table 5: The inhibition of cell growth by different cell lines of black bean.

\begin{tabular}{|c|c|c|c|c|c|c|c|}
\hline $\begin{array}{l}\text { Treatments } \\
\text { Conc. } \mu \mathrm{g} / \mathrm{mL}\end{array}$ & Raw & $\begin{array}{c}\text { Soaking } 2 \\
\mathrm{~h}+\text { Cooking }\end{array}$ & $\begin{array}{c}\text { Soaking } 6 \\
\text { h+Cooking }\end{array}$ & $\begin{array}{l}\text { Soaking } 12 \\
\text { h+Cooking }\end{array}$ & Germination 24 h & $\begin{array}{c}\text { Germination } \\
48 \mathrm{~h}\end{array}$ & $\begin{array}{c}\text { Germination } \\
72 \mathrm{~h}\end{array}$ \\
\hline 0.00 & 1.00 & 1.00 & 1.00 & 1.00 & 1.00 & 1.00 & 1.00 \\
\hline 5.00 & 0.867 & 0.925 & 0.926 & 0.960 & 0.853 & 0.785 & 0.858 \\
\hline 12.50 & 0.659 & 0.837 & 0.852 & 0.825 & 0.680 & 0.727 & 0.697 \\
\hline 25.00 & 0.260 & 0.630 & 0.585 & 0.535 & 0.428 & 0.320 & 0.539 \\
\hline 50.00 & 0.194 & 0.419 & 0.370 & 0.359 & 0.346 & 0.308 & 0.396 \\
\hline IC50 & 17 & 40 & 34.6 & 30.6 & 21.3 & 19.5 & 32.7 \\
\hline
\end{tabular}

Table 6: The inhibition of cell growth by different treatments of black bean

it is clear that the anticancer activity ascending with subsequent improvement of MCF7 cell line inhibition, $\mathrm{IC}_{50}$ was $19.5 \mu \mathrm{g} / \mathrm{mL}$ as a result of $48 \mathrm{~h}$ of germination. On contrary, anticancer activity realized a noticeable reduction of tumor inhibition after $72 \mathrm{~h}$ of germination, $\mathrm{IC}_{50}$ was $32.7 \mu \mathrm{g} / \mathrm{mL}$. The previous results support the view that prolonging the period of germination could enhanced the enzymes activity which affecting on the total phenolic content, the time affecting on the anticancer activity. Although $\mathrm{IC}_{50}$ of black bean extract increased after $72 \mathrm{~h}$ of germination, It conceder had cytotoxic activity.

Our results are in agreement with previous studies of Chan et al. [47] that demonstrated the antiproliferative activity of some components of beans, different from phenolic compounds, on human breast cancer (MCF7), human hepatoma (Hep G2) and nasopharyngeal carcinoma (CNE1 and CNE2) cell line.

\section{Conclusion}

The current study showed that ethanolic extracts of black beans have antioxidant and anticancer activities. The results observed that black beans had high total phenols, tannins and flavonoids. There were differences in these bioactive components as a result of soaking, cooking and germination processes. Anticancer activity realized a noticeable reduction of tumor inhibition. Soaking $12 \mathrm{~h}$ followed by cooking for $30 \mathrm{~min}$ and germination for $48 \mathrm{~h}$ exhibited higher anticancer activity relative to the other processing. It is clear that the anticancer activity ascending with subsequent improvement of MCF7 cell line inhibition.

\section{References}

1. Lajolo FM, Genovese MI (2002) Nutritional significance of lectin and enzyme inhibitors from legumes. J Agric Food Chem 50: 6592-6598.
2. Mathers JC (2002) Pulses and carcinogenesis: Potential foprevention of colon, breast and other cancers. British J Nutr 88: s273-279.

3. Silva MR, Silva MAAP (2000) Antinutritional factors: protease inhibitors and lectins. Revista de Nutrição 13: 3-9.

4. Ramirez-CL, Leonel AJ, Costa NMB (2008) Effect of domestic processing on nutrient and antinutritional factor content in different cultivars of common beans. Food Science and Technology 28: 200-213.

5. Muzquiz M (2008) Conference: Componentes nutricional menteactivos en leguminosas: implicaciones en nutricio' $n$ y salud. In: Scientific memories - 1 st International Scientific Congress and National Bean Fair (ed) Hernandez AC, Celaya, Me'xico: InstitutoNacional de Investigaciones Forestales, Agri'colas y Pecua rias.

6. Elnakish MT, Hassanain HH, Janssen PM, Angelos MG, Khan M (2013) Emerging role of oxidative stress in metabolic syndrome and cardiovascular diseases: important role of Rac/NADPH oxidase. J Pathol 231: 290-300.

7. Wang X, Wang W, Li L, Perry G, Lee HG, et al. (2014) Oxidative stress and mitochondrial dysfunction in Alzheimer's disease. Biochim Biophys Acta 1842: 1240-1247.

8. AOAC (2000) Official Methods of Analysis of the Association of Official Analytical Chemists. 17th edn. Horwitz W (ed.), Washington DC, USA.

9. Singleton VL, Rossi JA (1965) Colorimetry of total phenolics with phosphomolybdic-phosphotungstic acid reagents. Am J Enol Vitic 16: 144-158.

10. Zhishen J, Mengcheng T, Jianming W (1999) The determination of flavonoid contents in mulberry and their scavenging effects on superoxides radicals. Food Chem 64: 555-559.

11. Price ML, Socoyoc SV, Butler LG (1978) A critical evaluation of vanillin reaction as an assay for tannin in sorghum grain. J Agric Food Chem 26: 1214-1218.

12. Goupy P, Hugues M, Biovin P, Amiot MJ (1999) Antioxidant composition and activity of barely (Hordeum vulgare) and malt extracts and of isolated phenolic compounds. J Sci Food Agric 79: 1625-1634.

13. Mattila P, Astola J, Kumpulainen J (2000) Determination of flavonoids in plan material by HPLC with diode-array and electro-array detections. J Agric Food Chem 48: 5834-5841. 
Citation: Eshraq BK, Mona AM, Sayed AF, Emam AA (2016) Effect of Soaking, Cooking and Germination on Chemical Constituents and Bioactive Compounds as well as their Cytotoxic Activities of Black Bean Extracts. Nat Prod Chem Res 4: 237. doi:10.4172/2329-6836.1000237

Page 7 of 7

14. Williams W, Cuvelier ME, Berset C (1995) Use of a free radical method to evaluate antioxidant activity. LWT-FoodTech 28: 25-30

15. Skehan P, Storeng R, Scudiero D, Monks A, McMahon J, et al. (1990) New coloremtric cytotoxicity assay for anti-cancer durgs creening. J Natl Cancer Inst 82: 1107-1112.

16. Waller RA, Duncan DB (1969) A bayes rule for the symmetric multiple comparison problem. J Am Statistical Assoc 64: 1484-1503.

17. Vargas-Torres A, Osorio-DP, Tovar J, Paredes- Lopez O, Ruales J, et al (2004) Chemical composition, starch bioavailability and indigestible fraction of common beans (Phaseolus vulgaris L.). Starch 56: 74-76.

18. Carmona-Garcı'a R, Osorio-DP, Agama-Acevedo E, Tovar J, Bello-PLA (2007) Composition and effect of soaking on starch digestibility of Phaseolusvulgaris (L.) cv "Mayocoba". Int J Food Sci Technol 42: 296-302.

19. Osorio DP, Bello PLA, Sayago-Ayerdi SG, Reyes-Benitez MP, Tovar J, et al. (2003) Effect of processing and storage time on in vitro digestibility and resistant starch content of two bean (Phaseolus vulgaris L.). J Sci Food Agriculture 83 1283-1288.

20. Berrios JJ, Swanson BG, Cheong WA (1999) Physico-chemical characterization of stored black beans (Phaseolusvulgaris L.). Food Res Int 32: 669-676.

21. Fernández-Quintela A, Macarulla MT, Del Barrio AS, Martínez JA (1997) Composition and functional properties of protein isolates obtained from commercial legumes grown in northern Spain. Plant Foods Hum Nutr 51: 331-342.

22. Shaker AMH, Taha FA, Abdel Fattah SS (1995) Influence of some processing methods on chemical composition of lentil, faba bean and faba bean dishes. Bull Nutr Institute 15: 87-93.

23. Granito M, Frias J, Doblado R, Guerra A, Champ M, (2002) Nutritiona improvement of beans (Phaseolus vulgaris)by natural fermentation. Eur Food Res Technol 214: 226-231.

24. Candela M, Astiasaran I, Bello J (1997) Cooking and warm-holding: effect on general composition and amino acidsof kidney beans (Phaseolus vulgaris) chickpeas (Cicerarietinum), and lentils (Lens culinaris). J Agric Food Chem 45 4763-4767.

25. Mubarak AE (2005) Nutritional composition and antinutritional factors of mung bean seeds (Phaseolusaureus) as affected by some home traditional processes. Food Chem 89: 489-495.

26. Oliveira AC, Carraro F, Reis, Soely MPM (2001) The elimination of the not absorved water during common bean soaking resulted in weight gain in rats. Brazilian J Nutr 14: 153-155.

27. Oliveira AC, Queiroz KS, Helbig E, Reis SMPM, Carraro F (2001) The domestic processing of the common bean resulted in a reduction in the phytates and tannins antinutritional factors, in the starch content and in the raffinose, stachiose and verbascose flatulence factors. Arch Latinoam Nutr 51: 276-283.

28. López A, El-Naggar T, Dueñas M, Ortega T, Estrella I, et al. (2013) Effect of cooking and germination on phenolic composition and biological properties of dark beans (Phaseolus vulgaris L.). Food Chem 138: 547-555.

29. Cai Y, Luo Q, Sun M, Corke H (2004) Antioxidant activity and phenolic compounds of 112 traditional Chinese medicinal plants associated with anticancer. Life Sciences 74: 2157-2184.

30. Aguilera Y, Estrella I, Benitez V, Esteban RM, Martin-Cabrejas MA (2011) Bioactive phenolic compounds and functional properties of dehydrated beansflours. Food Res Intern 44: 774-780.
31. Xu B, Chang SKC (2008) Effect of soaking, boiling and steming on total phenolic content and antioxidant activities of cool season food legumes. Food Chem 110: 1-13.

32. Amarowicz R, Pegg RB (2008) Legumes as a source of natural antioxidants Eur J Lipid Sci Technol 110: 865-878.

33. Randhir R, Kwon YI, Shetty K (2007) Effect of thermal processing on phenolics, antioxidant activity and health-relevant functionality of select grain sprouts and seedlings. Innovative Food Sci \& Emerging Technolo 9: 355-364.

34. Kao H, Lu F, Hsieh C, Chan $\mathrm{H}$ (2004) Stability of isoflavone glucosides during processing of soymilk and tofu. Food Res Int 37: 891-900.

35. Buchner N, Krumbein A, Rhon S, Kroh L W (2006) Effect of thermal processing on the flavonols rutin and quercetin. Rapid Communications in Mass Spectrometry 20: 3229-3235.

36. Joseph O, Phelomene M, Helene N, Valen H, Patrick OM, et al. (2014) Phenolic Compound Profiles of Two Common Beans Consumed by Rwandans. Am J plant sci 5: 2943-2947.

37. Khandelwal S, Udipi SA, Ghugre P (2010) Polyphenols and tannins in Indian pulses: Effect of soaking, germination and pressure cooking. Food Res Int 43 : 526-530.

38. Shimelis EA, Rakshit SK (2007) Effect of processing on antinutrients and in vitro protein digestibility of kidney bean (Phaseolus vulgaris L.) varieties grown in East Africa. Food Chem 103: 161-172.

39. Duenas M, Hernandez T, Estrella I, Fernandez D (2009) Germination as a process to increase the polyphenol content and antioxidant activity of lupin seeds (Lupinusangustifolius L.). Food Chemi 117: 599-607.

40. Chai MY, Azrina A, Al-Sheraji SH, Abdulrahman HF, Nagendra PK (2011) Determination of antioxidant activities and total phenolic content in germinated and non-germinated legume extracts following alkaline-acid hydrolysis. Pakistan Journal of Nutrition 12: 1036-1041.

41. Saharan K, Khetarpaul N, Bishnoi S (2002) Antinutrients and protein digestibility of faba bean and rice bean as affected by soaking, dehulling and germination. $J$ Food Sci Techolo 39: 418-422.

42. Saxena AK, Chadha M, Sharma S (2003) Nutrients and antinutrients in chickpea(Cicerarietinum L.) cultivars after soaking and pressure cooking. J Food Sci Technol 40: 493-497.

43. Luthria DL, Pastor-Corrales MA (2006) Phenolic Acids Content of Fifteen Dry Edible Bean (Phaseolus vulgaris L.) varieties. J Food Composition Anal 19 205-211.

44. Friedman M (1997) Chemistry, Biochemistry, and Dietary Role of Potato Polyphenols. A Review. J Agric Food Chem 45: 1523-1540.

45. Makris DP, Rossiter JT (2000) Heat-induced, Metal-Catalyzed Oxidative Degradation of Quercetin and Rutin (Qercetin 3-O-Rhamnosylglucoside) in Aqueous Model. J Agric Food Chem 48: 3830-3838.

46. Murakami M, Yamaguchi T, Takamura H, Matoba T (2004) Effects of Thermal Treatment on Radical-scavenging Activity of Single and Mixed Polyphenolic Compounds. Food ChemToxico 69: FCT7-FCT10.

47. Chan YS, Wong JH, Fang EF, Pan W, Ng TB (2012) Isolation of a glucosamine binding leguminous lectin with mitogenic activity towardssplenocytes and antiproliferative activity towards tumor cells. PLoS One 7: e38961. 